\title{
EXERGY ANALYSIS OF DOUBLE-CIRCUIT FLAT SOLAR COLLECTOR WITH THERMOSYPHON CIRCULATION
}

\author{
Waldemar Wójcik ${ }^{1}$, Maksat Kalimoldayev ${ }^{2}$, Yedilkhan Amirgaliyev ${ }^{2,3}$, Murat Kunelbayev², \\ Aliya Kalizhanova, ${ }^{2,}$, Ainur Kozbakova, ${ }^{2,3}$, Timur Merembayev ${ }^{2}$ \\ ${ }^{1}$ Lublin University of Technology, Institute of Electronics and Information Technology, Lublin, Poland, ${ }^{2}$ Institute of Information and Computational Technologies SR MES RK, \\ Almaty, Kazakhstan, ${ }^{3}$ Al-Farabi Kazakh National University, Almaty, Kazakhstan
}

\begin{abstract}
In the present work, an exergy analysis was done of two-circuit flat solar collector with thermosiphon circulation. The article presents a mathematical model of energy and exergic analysis of flat solar collectors, as well as calculations of solar radiation efficiency, temperature, flow rate of the fluid, exergy rates and exergy loss rates are done. The significance of the results achieved is high, since experimental studies can detect inefficient components of the solar heating system. The exergetic efficiency of a dual-circuit flat solar collector with a thermosiphon circulation describes irreversibility of the process according to thermodynamic parameters. This is caused by a large the degree of overheating achieved at the end of the processes of compression and evaporation, which leads to large differences in heat exchange temperature based on the heat pump cycle. The exergy efficiency value for the entire system is 70. Maximum values energy efficiency and exergy at noon, $32.5 \%$ and $2.23 \%$, respectively. The efficiency of exergy is $4 \%$, and the highest the loss of exergy is the difference between the absorber plates and the sun, accounting for 52.86\% of the total exergy rate.
\end{abstract}

Keywords: temperature, solar energy, analysis, mathematical model

\section{ANALIZA EGZERGETYCZNA KOLEKTORA SLONECZNEGO DWUOBWODOWEGO Z OBIEGIEM TERMOSYFONU}

Streszczenie. W niniejszej pracy wykonano analizę egzergetyczna płaskiego kolektora słonecznego dwuobwodowego z cyrkulacja termosyfonowa. W artykule przedstawiono model matematyczny analizy energetycznej i egzergetycznej plaskich kolektorów stonecznych, a także obliczono sprawność promieniowania stonecznego, temperature, natężenie przepływu cieczy, wskaźniki egzergii $i$ wskaźniki strat egzergetycznych. Znaczenie osiagniętych wyników jest duże, ponieważ badania eksperymentalne moga wykryć nieefektywne elementy systemu ogrzewania energia słoneczna. Egzergetyczna sprawność dwuobwodowego płaskiego kolektora stonecznego z obiegiem termosyfonowym opisuje nieodwracalność procesu wedlug parametrów termodynamicznych. Jest to spowodowane dużym stopniem przegrzania osiaganym pod koniec procesów sprężania $i$ odparowywania, co prowadzi do dużych różnic $w$ wymianie ciepła $w$ oparciu o cykl pompy ciepła. Efektywność energetyczna całego systemu wynosi 70 . Maksymalne wartości sprawności energetycznej i egzergii w poludnie, odpowiednio 32,5\% i 2,23\%. Efektywność egzergii wynosi 4\%, a największa strata egzergii jest różnica pomiędzy plytami absorbera a słońcem, stanowiąca 52,86\% całkowitego wskaźnika egzergii.

Słowa kluczowe: temperatura, energia słoneczna, analiza, model matematyczny

\section{Introduction}

For water heating the power cost can be sufficiently reduced thanks to the solar energy usage. Thermosyphon solar collector is a type of a passive heater, which might be easily constructed and used without any complications. Thermosyphon thermal electric collector has been designed, constructed and tested at Dhaka University, Bangladesh [17]. Upon assessing the solar coil-type water heater the water temperature at the collector's inlet and outlet and in the reservoir were recorded during sequential hours. Maximum water temperature at the outlet from the collector accounted to $67^{\circ} \mathrm{C}$, and maximum water temperature in the reservoir constituted $61^{\circ} \mathrm{C}$ within June-July. Based on the collected data there have been constructed and analysed various temperature graphs for different sunny time, different insulation quantity and different weather conditions. There also has been conducted the $\mathrm{pH}$ test to study water $\mathrm{pH}$ value in the water reservoir made of alumina. Thermosyphon collectors' performance depends on several physical dimensions, operating parameters and meteorological parameters. While evaluating the efficiency, the attention is frequently paid merely to the thermal effectiveness. However, the energy equalizing does not consider many internal and conversion losses factors. High thermal effectiveness does not maintain the operation high performance [15]. The article [13] presents the theoretical model of the flat solar collectors' energy and exergy analyses, through which we can study the influence of all designed parameters at the operating characteristics.

To a greater extent, upon tracking the entropy generation, the exergy analysis using the thermodynamics second law might bring to the system operation optimization $[18,23]$. The denoted article pays the basic attention to the thermosyphon collector, considering its parameters in respect of the power consumption efficiency, as well, to dimensional, operational and meteorological parameters.

In the heat exchangers and solar water heaters for providing heat and hot water there widely used the serpentine tube. The system's dimensions physical parameters influence greatly at the performance. The serpentine tubes shall be precisely designed and placed within the system. The optimal position analysis of the calculated hydrodynamics of a serpentine heat exchanger is in contact with the drain with the carrier medium and length [9]. Wang et al. [22] have shown, that the exergy efficiency changes inversely to the collector width using the "Three stage theory». Comparing to other energy analysis theories, three theories' procedures have more advantages. The three procedures give an appropriate platform for conducting an energy analysis. An exterior analysis is executed with a purpose to provide some methods for cost saving and maintaining the solar water heater's performance at the local level at the demanded degree, and at the same time, to clarify the bounded losses at operation [3]. The solar fraction and configuration are sufficiently influenced with the absorber plate thermal conductivity [12]. Gupta et al. in the article [11] denoted, that there is an optimal temperature at the air inlet and mentioned parameters for a definite system, also, they analysed the dependence of air outlet energy on the ratio of the collector's dimensions, mass flow speed per the absorber's square unit and channel depth $[8,16]$ through the exergy analysis recommended the thermosyphon collector's optimal operation conditions. However, they supposed the constant inlet water temperature, which was equal to the atmospheric temperature. The authors thereof did not take into consideration the pressure drop. The proposed thermosyphon collector design method is based on the minimal entropy generation, but there was neglected the exergy destruction due to the pressure drop [21]. Farahat et al. [7] presented a detailed approach to the exergy analysis and optimization and showed, that the exergy performance constitutes $3,898 \%$ in the optimal state. Exergy analysis of multiple solar thermal collectors and processors have been thoroughly considered by many researchers [14]. The next article has given the exterior balance stages [20], the thermosiphon exergy optimization for dimensional and operational results. The stage thereof and optimal outcome might be used for other similar systems. In the work [19] there has been developed the optimization tools in the MATLAB media, which is used for 
defining the parameters of the exergy maximum performance. Parameters' values in the optimal state are used for studying the definite parameter impact at the system's efficiency. There has been mentioned a concise information about the exergy elimination and destruction in the works [4,7], nondimensional exergy [2] and an exergy destruction factor [5], which can be used for forecasting such type systems performance.

\section{Method of research}

Double circuit flat solar collector with thermosyphon circulation has been constructed and installed at the Institute of Information and computer technologies of MES RK, Almaty, Republic of Kazakhstan: 77 degrees of East longitude and 43 degrees of Northern latitude), as it is shown on the Figure 1. The installation has tubes over the absorber plate, which act according to a thermosyphon principle (Fig. 1 and 2). A flat collector slope angle is $45^{\circ}$, directed to the South. Water incomes to a collector through an inlet tube from a water tank and bleeds heat from an absorber plate.

Water tank: an isolated reservoir, containing water, used for maintaining the water stream into and out of the collector. Water density change inside the reservoir creates thermosyphon activity.

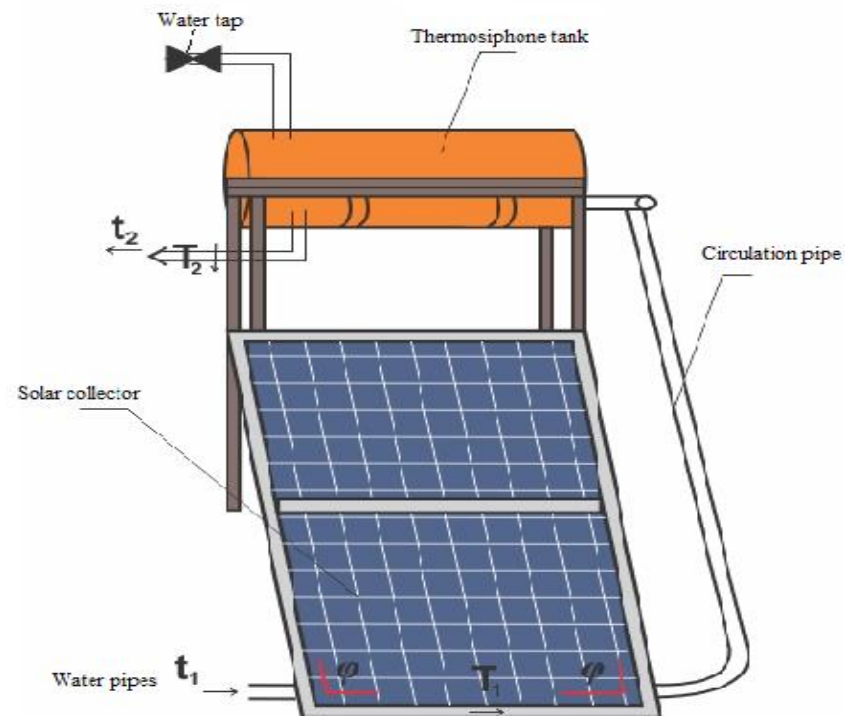

Fig. 1. General view of solar water heater

Substantiation of design technological scheme. With account of requirements to the installation's indices upgrading there has been developed the diagram of double circuit solar installation with a thermal pump (Figure 1), the installation is formed of four basic units: thermosyphon 1 , solar collector 2 , heat pump 3 , tank accumulator 4

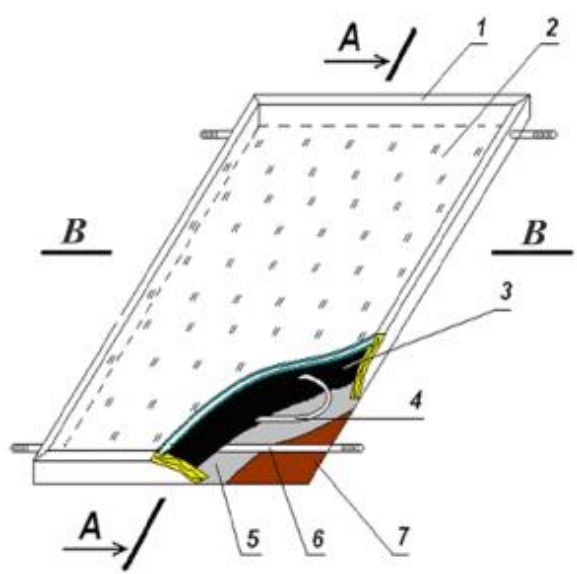

Fig. 2. Flat solar collector

Fig. 2 demonstrates the flat solar collector model. The installation's principle and novelty consists in its difference from the known designing principle, the collector contains a transparent double glazing unit 2 with reduced pressure, as well, a parametric frame 1. A wooden frame bottom 7 is made of $8 \mathrm{~mm}$ thickness plywood and there is fixed a heat sealing film to it 5 with foil. In the gap between a glazing unit and frame bottom there is laid a thin wall flexible stainless corrugated tube $4 \varnothing 16 \mathrm{~mm}$ in the coil form. Tube edges are fixed to the inlet and outlet obtrusive tubes 6 .

Table 1. Technical indicators of flat solar collector

\begin{tabular}{|l|r|}
\hline \multicolumn{1}{|c|}{ Parameters } & Value \\
\hline Absorbing plate material & $2 \mathrm{~m} \times 1 \mathrm{~m}$ \\
\hline Absorber plate dimensions & $0.4 \mathrm{~mm}$ \\
\hline Plate thickness & Hardened glass \\
\hline Glazing material & $2 \mathrm{~m} \times 1 \mathrm{~m}$ \\
\hline Glazing dimensions & $4 \mathrm{~mm}$ \\
\hline Glazing thickness & Foam plexus (foam polyurethane) \\
\hline Insulation & $45^{\circ}$ \\
\hline Collector's decline angle & $401 \mathrm{~W} /(\mathrm{m} \mathrm{K})$ \\
\hline Absorber's thermal conductivity & $0.04 \mathrm{~W} /(\mathrm{m} \mathrm{K})$ \\
\hline Insulation thermal conductivity & 0.855 \\
\hline Transmission-absorption factor & $4350 \mathrm{~K}$ \\
\hline Visual sun temperature & $303 \mathrm{~K}$ \\
\hline Atmospheric temperature & $1000 \mathrm{~W} / \mathrm{m}^{2}$ \\
\hline Irradiation intensity & \\
\hline
\end{tabular}

\subsection{Substantiation of design-technological scheme}

Due to the necessity of upgrading the installation's operational specifications we have developed a principle diagram of double circuit solar collector with a heat pump (Fig. 3).

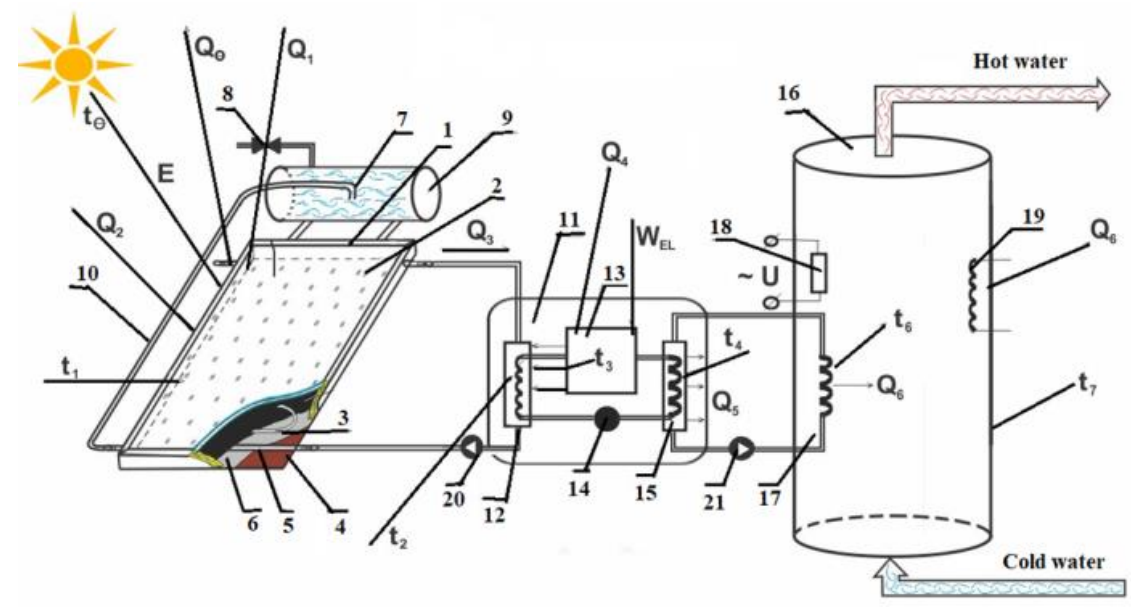


The assumed installation's operation is fulfilled as follows.

Solar energy $\mathrm{E}$ with temperature $\mathrm{t}_{0}$ is absorbed by the solar collector 1 , with the temperature $t_{1}$, which, heating the solar energy flow, passes through translucent insulating double glass unit 2 . The heat, obtained from the solar stream, heats the liquid in the coils 3 , which is removed from the collector, and replaced with cold water from the water pipe with a tap for cold water 8 , and in the dosing unit syphon 7 there takes place constant thermosyphon circulation by means of circulation tube 10 . Further the liquid flows into a heat pump 11, which consists of 12 - condenser with a temperature $t_{2}$, in which a heat exchanger is made in the coil form, absorbing the thermal medium heat, reduces its temperature lower than the atmospheric air temperature $\left(Q_{2}\right.$ by means of a speed control valve 14 , thereby helping on the additional heat absorption from the atmospheric air. The scheme also shows the solar irradiation, reflected from semi-transparent coating $\left(\mathrm{Q}_{0}\right)$ and absorbing panel surface $\left(Q_{1}\right)$. In the heat pump there is fulfilled a heat carrier power transfer with a relatively low temperature, to a condenser's heat exchanger transfer medium 15 in the coil form with higher temperature $t_{2}$, which increases the square, as well as the heat exchange intensity. To execute such a cycle there is used a compressor 13 with temperature $t_{3}$, electric drive 17 . Further, by means of the condenser heat exchanger 15 with temperature $t_{4}$, the heat from the heat pump $\left(\mathrm{Q}_{5}\right)$ is transferred to the heat exchanger tank-accumulator $\mathrm{Q}_{6}$ with temperature $\mathrm{t}_{6}$ of the heating system 18 . As the installation has two circuits, it is provided with automatic circulation pumps 19 and 20 for liquid circulation between the solar collector and evaporator, condenser and tank-accumulator. Water temperature is conditioned to the demanded technological level and provided the consumers for hot water and heating supply.

\subsection{Energy and exergy model}

Instant useful energy, accumulated by the solar collector is computed according to the following equations $[5,6,10]$

$$
Q_{u}=A_{\mathrm{c}} F_{R}\left[I_{T}(\tau \alpha)-U_{l}\left(T_{i n}-T_{a}\right)\right]=m C_{p, w a}^{\cdot}\left(T_{0}-T_{i}\right)
$$

Alternatively, the instant useful energy, accumulated with the solar collector might be computed as

$$
\dot{Q}_{u}=\dot{m} C_{p, w a}\left(T_{o u t}-T_{\text {in }}\right)
$$

Collector's instant performance is computed as

$$
\eta_{e n}=\frac{Q_{u}}{I_{T} A_{C}}
$$

Temperature distribution between the tubes and collector's efficiency factor is discussed in detail [10]

Let's write down the equations for the flow energy and exergy in the heat pump system and its components, as they are considered to be established with the system's flow volume, energy and exergy equations have been derived for the system and its components.

The heat, extracted from the heat pump heat exchanger $Q_{u}$ is computed according to the following equation:

$$
Q_{u}=\dot{m} C_{p}\left(T_{\text {out }}-T_{\text {in }}\right)
$$

Heat transfer factor in the condenser is computed as follows

$$
\dot{Q}=\dot{m}\left(h_{2}-h_{1}\right)
$$

Heat exchange speed in the evaporator amounts to

$$
\dot{Q}=\dot{m}\left(h_{1}-h_{4}\right)
$$

Compressor implementation speed [33]

$$
W_{\text {com }}=\frac{\dot{\dot{m}}_{r e f}\left(h_{2}-h_{1}\right)}{\eta}
$$

where $\eta$-energy efficiency

The total system efficiency factor «COPsys», which represents the ratio of the condenser load to the total expenditures on the compressor operation and circulation pumps is computed according to the following equation

$$
C O P_{\text {sys }}=\frac{\dot{Q}_{u}}{\left(\dot{W}_{\text {com }}+\dot{W}_{\text {pumps }}\right)}
$$

Working inlet into the circulation pump [36]

$$
W_{\text {pump }}=\frac{\Delta P V}{\eta}
$$

where $\Delta \mathrm{P}$ - pressure loss, $\mathrm{V}$ - volume flow rate of water - glycolic mixture, $\eta$ - the pump mechanical performance.

$\Delta \mathrm{P}$ - pressure loss is recorded as:

$$
\Delta \mathrm{P}=0.5 \mathrm{f} \frac{L}{D} \rho U^{2}+\sum \zeta
$$

where $\mathrm{U}-$ speed, $\mathrm{f}-$ fraction losses, $\zeta$ - resistance specific loss, $\mathrm{L}$ - tube length.

Exergy speed is calculated according to the following equation

$$
\dot{E}_{x}=\dot{m}_{r e f}\left[\left(h-h_{0}\right)-T_{0}\left(s-s_{0}\right)\right.
$$

Exergy destructions in the heat exchanger (condenser and evaporator), in the expansion valve and solar collector are computed as follows:

Heat exchanger:

$$
\begin{gathered}
\dot{E}_{\chi d e s t, H E}=\sum \dot{E}_{\chi i n}-\sum \dot{E}_{\chi o u t}-\sum \dot{E}_{\chi \text { dest }} \\
\dot{E}_{\chi d e s t, H E}=m_{w a}\left(\psi_{\text {in }}-\psi_{\text {out }}\right)+\dot{Q}_{r}\left(1-\frac{T_{0}}{T_{\text {ground }}}\right)
\end{gathered}
$$

Thermal pump

Expansion valve:

$$
\dot{E}_{\chi \text { dest }, \text { pump }}=\dot{W}_{\text {pump }}-\left(\dot{E}_{\chi o u t}-\dot{E}_{\chi i n}\right)
$$

$$
\dot{E}_{\chi d e s t, v a l v e}=m_{\text {ref }}\left(\psi_{\text {in }}-\psi_{\text {out }}\right)
$$

Entry mode, which is used as a solar collector:

$$
\begin{gathered}
\dot{\mathrm{E}}_{\chi \text { dest }, \mathrm{col}}=\mathrm{m}_{\mathrm{wa}} \cdot\left(\psi_{\mathrm{in}}-\psi_{\text {out }}\right)+\dot{\mathrm{Q}}_{\mathrm{u}}\left(1-\frac{\mathrm{T}_{0}}{\mathrm{~T}_{\mathrm{s}}}\right) \\
\dot{E}_{\chi \text { dest }, \text { col }}=m_{w a}\left(\psi_{\text {in }}-\psi_{\text {out }}\right)+A_{C} I_{T}\left(1-\frac{T_{0}}{T_{S}}\right)
\end{gathered}
$$

Heat exchangers (condenser and evaporator) exergy efficiency is defined through increasing the cold flow exergy, divided by decrease of hot flow exergy on the basis of speed as follows:

$$
\varepsilon_{H E}=\frac{\dot{m}_{\text {cold }}\left(\dot{\psi}_{\text {cold }, \text { out }}-\dot{\psi}_{\text {cold in }}\right)}{\dot{m}_{\text {hot }}\left(\psi_{\text {hot }, \text { in }}-\phi_{\text {hot }, \text { out }}\right)}
$$

Circulation pumps exergy performance is determined with an equation:

$$
\varepsilon_{\text {pump }}=\frac{\dot{E}_{\chi o u t}-\dot{E}_{\chi i n}}{\dot{W}_{\text {pump }}}
$$

GSHPS exergy efficiency is computed:

$$
\varepsilon_{\text {sys }}=\frac{\dot{E}_{\text {Xout }}}{\dot{E}_{\chi i n}}=1-\frac{\sum \dot{E}_{\chi \text { dest }}}{\sum \dot{E}_{\text {in }}}
$$

\section{Research outcomes}

In the research herein we have conducted the energy and exergy studying the analysis of dual circuit flat solar collector with thermosyphon circulation. Figure 4 shows the hourly change of solar radiation intensity and atmospheric temperature as regard to Almaty city, Kazakhstan (longitude /latitude:77 degrees of East longitude and 43 degrees of North latitude).

The authors of the article herein have considered the solarenergetic resources of the Republic of Kazakhstan. To assess the potential of the solar energy, falling onto the territory in one or another district, it is necessary to have the data on the solar power potential. Having generalized the actual observations and theoretical calculations there has been obtained data on: annual and latitudinal movement of possible monthly and annual amounts of direct solar radiation falling onto the perpendicular surface at clear sky conditions, information on sunshine period, solar radiation daily movement for typical days of the year, maps of distributing the average monthly radiation sums along the territory within June and December, as well, the distribution maps of «technically applicable and economically profitable solar power», developed criteria for defining the conception. In the root of all solar systems designed indices upon assessing the solar-energetic resources on Kazakhstan territory there are laid. The qualitative characteristics of direct solar radiation, falling on the horizontal surface, which can be used for recomputation of any orientation from horizontal to inclined plane. Proceeding from statistical processing the direct total radiation average values and sunshine period there have been differentiated five zones and drawn up a histogram, characterizing the opportunities of implementing the solar installations on the territory of Kazakhstan [1]. 
To calculate the exergy analysis we have applied the computer simulation program (subprogram MATLAB ode45), based on Runge-Kutta quartic method for solving the above-mentioned non-linear ordinary differential equations. To secure the elaborated numerical model's accuracy, the water capacity numerical results have been confirmed with corresponding experimental temperatures [12].

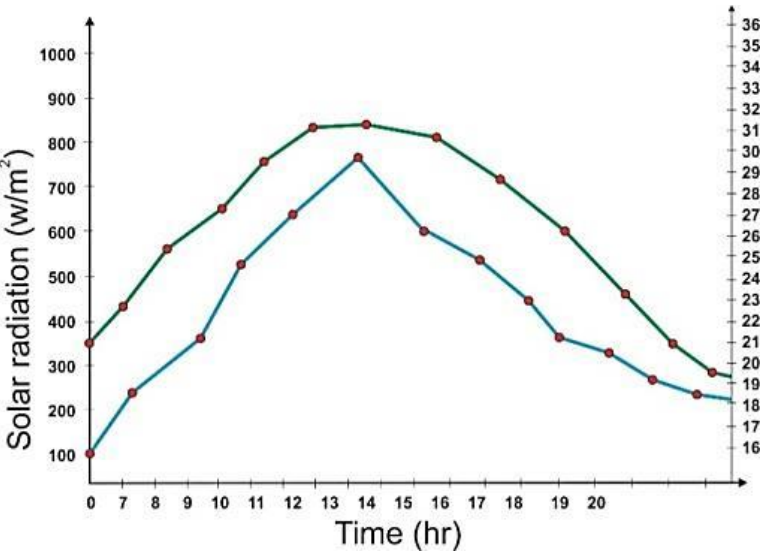

Fig. 4. Dependence of the solar radiation on hourly change of meteorological conditions in Almaty city (Kazakhstan)

Figure 4 show offered system's hourly energy and exergy efficiency change and all components exergy destruction speed. According to the dependence thereof it can be said, that the solar radiation intensity for Almaty city in summer period is of the most value at midday, as the total solar radiation reaches its peak height.



Fig. 5. Exergy performance indices of double circuit flat solar collector with thermosyphon circulation

Figure 5 presents the exergy performance indices of double circuit flat solar collector with thermosyphon circulation. As it is seen from the figure, the most process irreversibility judging from the thermodynamic indices is conditioned by the heat pump compressor. It is due to the overheat great extent, achieved in the end of compression and evaporation processes, which brings to big temperature gradient, linked with the heat exchange initial phase based on the heat pump cycle. Exergy performance value for overall system equals to 70. Reasons for exergy destruction in the system include a compressor, heat exchanger (condenser and evaporator), and circulation pumps. Water and coolant thermodynamic properties (working liquid, R218 have been obtained from the database NIST.

\section{Conclusion}

Exergy analysis of the flat solar collector with thermosyphon circulation is based on the heat losses factor calculation, collector's heat release coefficient and the plate impact factor. But, accuracy computation will lead to the perfection. In the work herein it has been proved, that maximum exergy level can be reached with the temperature range, but the heat pump efficiency factor lowers, at that, the atmospheric temperature makes a positive influence at thermal effectiveness, while it negatively affects the exergy performance. As well, it has been proved, that at circulating solar water supply system the exergy efficiency can be about $4 \%$.

\section{Acknowledgements}

This work is supported by grant from the Ministry of Education and Science of the Republic of Kazakhstan within the framework of the Project BR05236693 "Mathematical and computer models, hardware and software tools and experimental development on creation of network combined effective dualcircuit solar collectors with thermosiphon circulation and monitoring of their functioning".

\section{References}

[1] Amirgaliyev Ye.N., Kunelbayev M, Wójcik W, Kalizhanova A.U., Auyelbekov O.A., Katayev N.S., Kozbakova A.Kh., Irzhanova A.A.: Solardriven resources of the republic of Kazakhstan. News of The National Academy of Sciences of the Republic of Kazakhstan, Series of Geology and Technical Sciences 4(430)/2018, 18-27.

[2] Arora A., Kaushik S.C.: Theoretical analysis of a vapour compression refrigeration system with R502, R404A and R507A. Int. J. Refrig. 31/2008, 998-1005.

[3] Ben H.: Analysis and Synthesis of Energy Utilization. Chinese Petrochemical Engineering Press, Beijing 1995

[4] Cengel Y.A., Boles M.A.: Thermodynamics and Engineering Approach McGraw-Hill, Boston 2005

[5] Duffie J.A, Beckman W.A.: Solar engineering of thermal process. John Wiley and Sons Inc., Canada 1974

[6] Duffie J.A, Beckman W.A.: Solar engineering of thermal process. Wiley, New York 1991

[7] Farahat H.A.S., Sarhaddi F.: Exergetic optimization of flat plate solar collectors. Renew. Energy J. 8/2009, 1169-1174.

[8] Ge Z., Wang H., Wang H., Zhang S., Guan X.: Exergy analysis of flat plate solar collectors. Entropy 16/2014, 2549-2567.

[9] Gertzos K.P., Caouris Y.G., Panidis T.: Optimal design and placement of serpentine heat exchangers for indirect heat withdrawal, inside flat plate integrated collector storage solar water heaters (ICSSWH). Renew. Energy $35 / 2010,1741-1750$

[10] Goswami D.Y., Kreith F., Kreider J.F.: Principles of solar engineering. Taylor \& Francis, Pasadena 2000.

[11] Gupta M.K., Kaushik S.C.: Exergetic performance evaluation and parametric studies of solar air heater. Energy 33/2008, 1691-1702.

[12] Hossain M.S., Saidur R., Fayaz H., Rahim N.A., Islam M.R., Ahamed J.U., Rahman M.M.: Review on solar water heater collector and thermal energy performance of circulating pipe. Renew. Sustain. Energy Rev. 15/2011, 38013812.

[13] Jafarkazemi F., Ahmadifard E.: Energetic and Exergetic evaluation of flat plate solar collectors. Renew. Energy 56/2013, 55-63.

[14] Kalogirou S.A., Karellas S., Braimakis K., Stanciu C., Badescu V.: Exergy analysis of solar thermal collectors and processes. Prog. Energy Combust. Sci. 56/2016, 106-137.

[15] Liu R.H.T.G., Cengel Y.A.: Exergy Analysis of Solar Heating System. J. Sol. Energy Eng. 117/1995, 249-251.

[16] Luminosu I.; Fara L.: Determination of the optimal operation mode of a flat solar collector by exergetic analysis and numerical simulation. Energy 30/2005, 731-747.

[17] Mahadi M.S.-U.-R., Hasan M.F., Ahammed A., Kibria M.T., Huque S.: Construction, fabrication and performance analysis of an indigenously built serpentine type thermosyphon solar water heater. Proceedings of the 2014 3rd International Conference on the Developments in Renewable Energy Technology (ICDRET), Dhaka, Bangladesh, 29-31 May 2014, 2-7.

[18] Marletta L.: Air conditioning systems from the 2nd law perspective. Entropy 15/2013, 859-877.

[19] Matlab Optimization Toolbox, https://www.mathworks.com/products/ optimization.html (available 1.06.2019).

[20] Suzuki A.: General theory of exergy-balance analysis and application to solar collector. Energy 13/1988, 153-160.

[21] Torres-Reyes E., Gortari J.C., Ibarra-Salazar B., Picon-Nuñez M.: A design method of flat-plate solar collectors based on minimum entropy generation. Exergy Int. J. 1/2001, 46-52.

[22] Xiaowu W., Ben H.: Exergy analysis of domestic-scale solar water heaters Renew. Sustain. Energy Rev. 9/2005, 638-645.

[23] Yazdi M., Aliehyaei M., Rosen M.A.: Exergy, economic and environmenta analysis of gas turbine inlet air cooling with a heat pump using a novel system configuration. Sustainability 7/2015, 14259-14286. 
Prof. Waldemar Wojcik

e-mail: waldemar.wojcik@pollub.pl

Director of Institute of Electronics and Information Technologies, Faculty Electrical Engineering an Computer Science, Lublin University of Technology.

Doctor of Technical Sciences, Professor.

Scientific interests: mathematical modelling, optical fibre in telecommunication systems and networks, electronic devices, Bragg fibre gratings, fibre optic sensors.

\section{ORCID ID: 0000-0002-0843-8053}

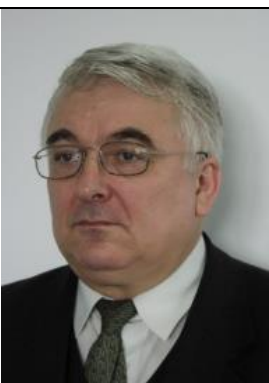

\section{Prof. Maksat Kalimoldayev}

e-mail:mnk@ipic.kz

Academician of NAS RK, doctor of physical and mathematical sciences, professor, Vice President, Chief Scientific Secretary of the National Academy of Sciences of the Republic of Kazakhstan the General director of the Institute of Information and Computational Technologies of the Ministry of Education and Science CS of the Republic of Kazakhstan. Research areas: modelling, control and optimization of complex systems, information security, artificial intelligence technology, robotic systems, speech technology, etc.

ORCID ID: 0000-0003-0025-8880

\section{Prof. Yedilkhan Amirgaliyev}

e-mail: amir_ed@mail.ru

Doctor of technical sciences, professor, head of the laboratory of mathematical and computer modelling of the Institute of Information and Computing Technologies of the Science Committee of RK MES The Institute is the leading organization in the field of information technology in the country. The main directions of the research laboratory is an intelligent decision-making systems, robotics, wireless senso technology, computer modelling of technological processes, etc.

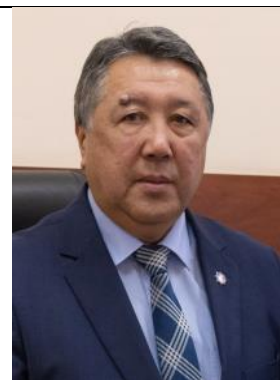

ORCID ID: 0000-0002-6528-0619

M.Sc. Murat Kunelbayev

Master of physics, a senior fellow at the Institute of Information and Computational Technologies of the Ministry of Education and Science CS of the Republic of Kazakhstan. Research interests: Simulation model of microhydroelectric power plant, solar collector, energy, technology design of complex systems.

ORCID ID: 0000-0002-5648-4476

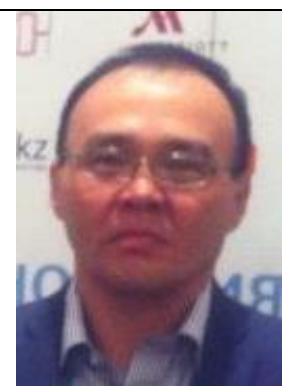

Ph.D. Aliya Kalizhanova

e-mail: kalizhanova_aliya@mail.ru

Candidate of physical and mathematical sciences, associate professor, the deputy general director of the Institute of Information and Computational Technologies of the Ministry of Education and Science CS of the Republic of Kazakhstan. Scientific interests of the leader: mathematical modelling of systems, models of transport systems network analysis, optimization methods, technologies for developing sensor systems for signals receivetransmit, mathematical modelling of Bragg fibre gratings.

ORCID ID: 0000-0002-0843-8053

\section{Ph.D. Ainur Kozbakova}

e-mail: ainur79@mail.ru

Ph.D. on a specialty "Information Systems", a senior fellow at the Institute of Information and Computational Technologies of the Ministry of Education and Science CS of the Republic of Kazakhstan. Research interests: mathematical modelling of discrete systems, evacuation tasks, operations research, technology design of complex systems.

ORCID ID: 0000-0002-5213-4882

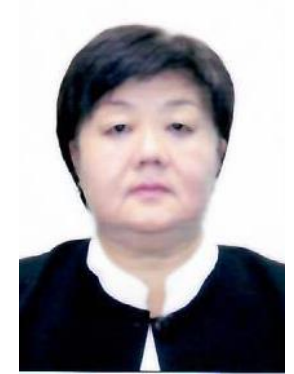

M.Sc. Timur Merembayev

e-mail:merembaevt@gmail.com

Ph.D. Student specialising in "Information Systems", a programmer at the Institute of Information and Computational Technologies of the Ministry of Education and Science CS of the Republic of Kazakhstan. Research interests: mathematical modelling of discrete systems, evacuation tasks, operations research, technology design of complex systems.

ORCID ID: 0000-0001-8185-235X

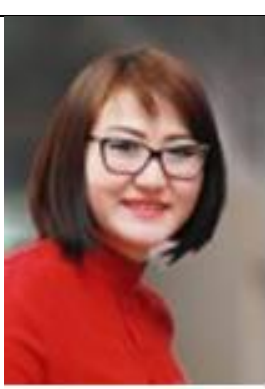

otrzymano/received: 30.05 .2016

przyjęto do druku/accepted: 15.06 .2019 